\title{
Un testimonio multigeneracional: La traducción, una herramienta más contra el genocidio. Selección de poemas de Ruth Irupé Sanabria
}

\author{
A multigenerational testimony: Translation, one more tool against genocide. \\ Selection of poems by Ruth Irupé Sanabria
}

\author{
Alicia Partnoy \\ APartnoy@lmu.edu \\ Loyola Marymount University, Estados Unidos
}

Recepción: 04 Noviembre 2020

Aprobación: 15 Noviembre 2020

Publicación: 01 Diciembre 2020

Cita sugerida: Partnoy, A. (2020). Un testimonio

multigeneracional: La traducción, una herramienta más contra el genocidio. Selección de poemas de Ruth Irupé Sanabria. Aletheia, 11(21), e081. https://doi.org/10.24215/18533701e081
Resumen: Presentación de la poeta Ruth Irupé Sanabria, selección de poemas y traducción a cargo de su madre, la escritora Alicia Partnoy.

Palabras clave: Poesía, Traducción, Genocidio, Trauma.

Abstract: Presentation of the poet Ruth Irupé Sanabria, selection of poems and translation by her mother, the writer Alicia Partnoy.

Keywords: Poetry, Translation, Genocide, Trauma.

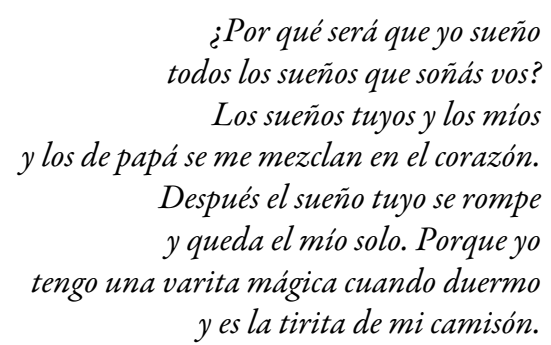

Fuente: Ruth Irupé Sanabria (Seattle, 1980)

Cuando Ruth me reveló que la presente selección de su obra - que yo me había ofrecido gustosa a traducirtendría como eje unificador el trauma causado por la dictadura militar, mi corazón dio un vuelco. La tarea sacudiría todo el andamiaje profesional con el que suelo protegerme. Traducir contra el genocidio es, frecuentemente, traducir en carne viva. 
Mi hija comenzó a procesar sus experiencias traumáticas en poesía a una edad muy temprana. Atesoro junto a las viejas fotos los primeros poemas que compartió conmigo a pocos días de nuestra llegada al exilio. Tenía cuatro años y un camisón con tiritas que todavía no había aprendido a atar, con el que bailaba sobre la cama improvisada en el living frente a un inmenso televisor a color.

Nos recuperábamos: Yo con alegría y un optimismo que no sabía ver mi propio trauma, ella con una ternura inmensa hacia esa "mamita" casi desconocida y una angustia que la hacía despertar con pesadillas y llorando por su Argentinita. Habíamos vivido tres años de separación por la desaparición mía y de su padre y nuestro posterior encarcelamiento a manos de la dictadura militar genocida. Ella extrañaba a quienes habían sido su "mamá y papá" (mis padres) y a mi hermano que a los 22 años era el espíritu con quien más se entendía en ese mundo absurdo disfrazado de cotidianeidad para que la nena no sufriera tanto. Pocos años después, su suicidio nos dejó sin aire y su figura se esfuma en las pinturas de mi madre, Raquel Partnoy, cabalga decapitada en los poemas de Ruth y vuelve a despertar una niñez idílica en los míos.

Con mi hermano estudiamos inglés sin muchas ganas y durante largos años en la Asociación Bahiense de Cultura Inglesa. Sin embargo, apenas unos meses después de aterrizar en los Estados Unidos, Ruth ya lo hablaba mejor que yo. Ella asistía a un jardín de infantes bilingüe llamado José Martí en el Centro de la Raza (un emprendimiento de la comunidad chicana en Seattle). A esa ciudad rodeada de montañas y lagos en el noroeste de los Estados Unidos no habíamos elegido llegar. Sin embargo, quiso recibirnos y nos abrazó con la solidaridad de su gente y la del resto de la colectividad de refugiad@s argentin@s y chilen@s que compartían heridas similares a las nuestras. Cerca de allí, en Spokane, asistí a una conferencia de Amnistía Internacional donde escuché cómo el brillante poeta Dennis Brutus, quien había estado preso con Mandela, matizaba su testimonio del genocidio en Sudáfrica con sus propios poemas. Desde ese momento comencé a pedir ayuda para tratar de volcar mi poesía al inglés. Muchas veces era Ruth quien me alcanzaba la palabra precisa.

En su adolescencia y luego en la universidad, Ruth siguió perfeccionando sus dotes de poeta, estudiando creación literaria en las aulas de Rick Kearns, Derek Walcott, Philip Levine, Elizabeth Alexander y otres y escribiendo con una disciplina y constancia más cercanas a las que siempre ha ejercido mi madre con su pintura que yo con mi propia poesía.

Hace ya casi veinte años comenzamos las tres a presentar nuestro testimonio multigeneracional en diversas universidades de los Estados Unidos. Proyectamos las pinturas de mi madre, Raquel Partnoy, mientras leemos nuestros poemas y ella habla del contexto político y social en que su pintura fue evolucionando. Mamá, después de que una maculopatía le augurara una futura ceguera, comenzó a dedicarse a la poesía. Es así como, a los 81 años publicó su primer poemario: Ciudad de rojos horizontes. El libro en que nuestra casa de Bahía Blanca donde crecimos mi hermano y yo es testigo de la destrucción ocasionada por la dictadura genocida, fue escrito en inglés. Con múltiples diccionarios y recurriendo a Ruth y a mí para pulir su trabajo, mi madre decidió encarar ese largo poema autobiográfico en otro idioma. El concentrarse en cómo decir el dolor en esa lengua que estaba aprendiendo le permitía tomar distancia de las memorias angustiantes. Posteriormente, ante el ofrecimiento de publicación por parte de la solidaria editorial bahiense Hemisferio Derecho, tradujo sus poemas al castellano. Su poesía retornó entonces al epicentro del trauma.

Hace un par de semanas en una de nuestras performances multigeneracionales una estudiante nos preguntó si esas presentaciones eran una colaboración. Ruth y yo respondimos que más bien se trataba de coincidencias por la experiencia vivida y los lazos que nos unen. Agregué lo que Raquel siempre dice, que sus dibujos en todos mis poemarios y en La Escuelita. Relatos testimoniales no son ilustraciones, no se generan para ilustrar lo escrito sino que son sus propios trabajos que armonizan con los textos. Esta última vez, mi madre no pudo participar en persona por los avatares propios de la pandemia, pero una joven artista preparó un audiovisual que garantizó su presencia ${ }^{1}$.

Las coincidencias suelen sorprendernos a nosotras mismas. Recuerdo que hace diez años, en la American University de Washington, después de que yo leyera "A mi hija: Carta desde la cárcel” mi madre compartió un poema suyo sobre sus visitas a la cárcel de Villa Devoto: 
"Detrás de la alta fachada. Bienvenida”, de Raquel Partnoy

\section{$A$ las 13 bs.}

¡Ladrones a la derecha! ¡Subversivos a la izquierda!

Nosotros - subversivos, nos ubicamos

confortablemente a lo largo de la alta fachada bañada por la persistente lluvia.

\section{$A$ las 15 bs.}

Gentilmente nos invitan a entrar en el edificio y envian al lugar de inspección.

Guardianas con manos delicadas nos revisan $y$ tocan por todos lados para ver

si traemos objetos peligrosos. Esto es necesario de hacer! Mi nieta de tres años

pudo haber olvidado dejar en casa las hojas de afeitar y cuchillos pequeños

con los que suele jugar y traerlos escondidos entre su ropa, o en su cuerpo.

\section{$A$ las 16 bs.}

Como seguro corresponde la fila de la derecha pasa a visitar sus familiares detenidos

primero, mientras la nuestra es mandada a la iglesia de la cárcel para esperar

$y$ disfrutar por horas el lugar. Cuando le decimos a un guardia que tenemos

sed éste, con amplia sonrisa y cortés contesta: ¡Vayan a pedirle agua a Dios!

\section{A las 18hs.}

Vienen dos guardias y piden que los sigamos. Mientras cruzamos portones nos llega 


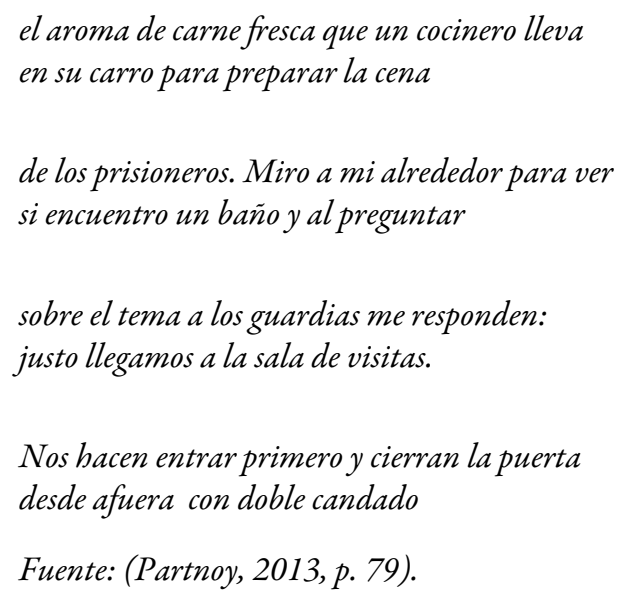

Mientras mamá recitaba estas estrofas, Ruth escuchaba visiblemente impactada. Luego recitó un fragmento de “iOh ventana infame!” sobre su propia experiencia ese mismo día:

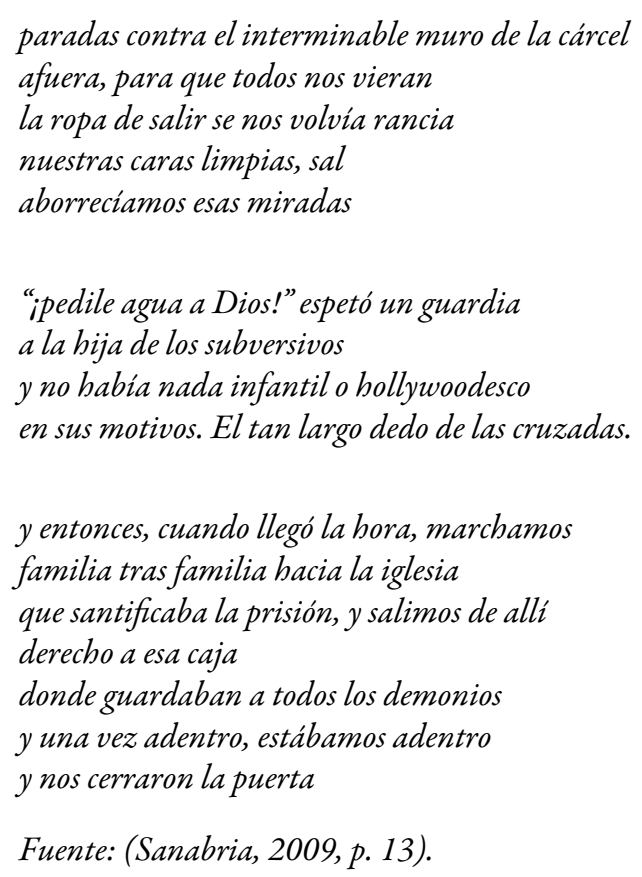

Pero llegó la hora de la justicia y las tres testificamos en el juicio definitivo, el que finalmente pondría a los genocidas bahienses en el lugar que merecían. Mamá y Ruth declararon por teleconferencia y las experiencias presentes en sus poemas y pinturas se convirtieron en quemante relato del dolor y las humillaciones sufridas. El juicio en dos tramos, por esas cosas que yo llamo marxismo mágico, comenzó el día del cumpleaños de Ruth (28 de junio del 2011) y terminó el día del cumpleaños de su hija Dulce, el 17 de diciembre de 2013.

Para profundizar sobre mi atención a estas fechas y su conexión con nuestro testimonio multigeneracional, es útil recurrir a los conceptos de Gottfried Bloch. Este psicoanalista y sobreviviente del Holocausto describe cómo sus experiencias en el campo de concentración "interfieren con la felicidad presente... magnificando las ansiedades del mañana” (Bloch, 2004, p. 3). Contra eso que llama "asociaciones no libres”, Bloch se apoya en lo que Heinz Kohut define como "eje temporal”, o sea el sentido interno de continuidad del tiempo en la vida de una persona. Bloch escribe: "El reestablecer esa continuidad después de la fragmentación traumática 
sufrida fue una parte importante de mi retorno a una vida plena. La continuidad del eje temporal desde sus raíces en el pasado lo conecta con el futuro y con el logro de aquellas, nuestras metas tempranas" (p. 4).

En nuestro caso, ese eje temporal se fortalece con el testimonio multigeneracional que, debido a las circunstancias a que nos forzó el exilio, apela a la traducción como herramienta fundamental en nuestra lucha por la Justicia, la Verdad, la Memoria.

Alicia Partnoy. Los Ángeles, 4 de diciembre de 2020

(día en que mi hermano Daniel hubiera cumplido 62 años)

\section{Selección de poemas de The strange house testifies: Poems (2009) y Beasts behave in FOREIGN LAND (2017) De Ruth Irupé SANABRia}

\section{On Reconciliation \#2}

We take the cellphones in our pockets for granted

as if prison microphones

like the cold moon,

relatively close and visible but

impossible to touch with hands unbound,

I mean with bare hands,

I mean without glass or metal,

did not lay some gravity upon our tongues -

I mean censorship and loss of love.

I say, we take planes \& extra house keys as if permission paper and visit denied are forgettable, and the promises forged in cold cells and on lone swings do not need to fly, enter a house and speak, simply and from a place the moon can not touch.

\section{Sobre la reconciliación.II}

Llevamos el celular en el bolsillo como si nada como si micrófono carcelario como si fría luna, relativamente cerca y visible pero imposible de tocar con las manos desatadas, quiero decir a mano limpia, quiero decir sin vidrio ni metal sin algo solemne pesándonos sobre la lengua quiero decir censura y pérdida de amor-.

Digo, tomamos aviones \& copias de llaves como si permisos y visitas negadas fueran olvidables, si promesas forjadas en celdas frias y solitarias hamacas infantiles no necesitaran volar, entrar a casa y hablar, con simpleza $y$ desde un sitio totalmente intocable por la luna.

\section{Refugees in the Attic on Lamont Street}

We are the resident ghosts, atheist in the blue dollhouse. 
Our hosts are white and subversive

and devoted to Jesus.

I descend from their attic.

I want their mints and their chocolate bunnies.

God will punish me

if I steal.

How to not bend in confusion

or in desperate gratitude,

how to not be too quiet when seen,

how to listen to their language, befriend their wordsthese things my mother shows me.

To rebuild my body,

I watch her build her own.

I spin alone in the quiet attic room.

I spy on raccoons from the edges of the attic window. I float back across the sky.

Yes, the walls warm.

$Y$ es, the floors hold.

Their roof is stable, yes.

Without scandalous sounds

they raise their wineglasses to us.

They break bread with us.

We hold our tongues.

We drop our heads

for grace.

Refugiados en el altillo de la Calle Lamont

Somos fantasmas en residencia,

Ateos en esta azul casa de muñecas.

Nuestros anfitriones son blancos y subversivos $y$ devotos de Jesús.

Desciendo del ático.

Ansio sus golosinas y conejos de chocolate.

Dios me castigará

si me los robo.

Cómo no inclinarse en señal de confusión

o desesperada gratitud,

cómo no petrificarse si te ven,

cómo escuchar su idioma, hacerse amiga de sus palabras

- cosas que mi madre me enseña-.

Reconstruyo mi cuerpo

viéndola construir el suyo. 
Sola giro en el callado altillo.

Espio a los mapaches desde el borde de la ventana

$Y$ voy flotando de regreso por el cielo.

Si, entibian las paredes.

Sí, los pisos contienen.

Su techo es sólido, sí.

Sin sonidos escandalosos

alzan sus copas de vino en nuestro honor.

Con nosotros comparten el pan.

Nos mordemos la lengua.

Bajamos la cabeza

para dar gracias.

\section{Lunchbox Note \#1}

"You and I are safe." I keep those words to myself in a locket I hang inside my throat.

In the galaxy of our memories are forests filled with hunters. In the galaxy of our memories, ink sticks and moons, halved and holed, document the tourniquets of delirium. I don't want the poison of revolving memories on you.

First, the sun lacerates the sky into opal, opens all the animal eyes, and arches across your jogging path. The doe and her fawn wonder what danger is the human running.

Guilt leaves behind a bedazzling trail dissolved with simple table salt. I will keep the tragedies, old and book-bound on the top shelf. Pull down the words if you need history. Administer the stories yourself. I retract the terrible. Into your warm palms I drop the little silver anchor of imagination. I release you from heirlooms. I throw out the family lexicon on the suffering. Forget how children knew their mothers.

\section{Nota № 1 en la mochila escolar}

"Vos y yo estamos a salvo". Guardo para mi estas palabras bajo candado en la garganta. En la galaxia de nuestras memorias bosques repletos de cazadores. En la galaxia de nuestras memorias, tinta grumosa y lunas partidas y huecas documentan los torniquetes del delirio. No quiero sobre vos el veneno de las memorias giratorias.

Al principio el sol lacera el cielo en ópalos, abre ojos animales, arquéase sobre el sendero en que corres. La cierva y su cría miden el peligro del corredor humano.

La culpa deja atrás un camino deslumbrante disuelto en sal. Guardaré las tragedias, viejas y encuadernadas, en el estante más alto. Arrancá las palabras si precisás historia. Administrá vos los relatos. Me retracto de lo terrible. En tus tibias palmas dejo caer, cual dije, el ancla de plata de la imaginación. Te libero de tus reliquias. Descarto el lexicón familiar del dolor. Olvidá el modo en que las criaturas conocen a sus madres. 
Aletheia, vol. 11, $\mathrm{n}^{\circ}$ 21, e081, diciembre 2020-mayo 2021, ISSN 1853-3701

\section{Tatuaje}

A spirit came down

and whispered in our drunk ears

mark your wombs with wild roses

and between beers I dreamed

that we were soldiers missing our mothers

which explains why we are seventeen

and in a tattoo parlor that smells of ships and motorcycles,

of leather and ocean, of marijuana and sad men's blood.

We each ask for a single rose

with a ribbon around the stem,

for a word, some power.

We want to be fire.

The artist changes channels.

We watch Looney Tunes as his needles start.

When we stop at the liquor store,

our roses, orange and violet, bleeding through the bandages,

I want to tell you that if we ever find ourselves blindfolded in a war, or in an apple metaphor, accused of ruining it for everybody

with hunger, or knowledge,

I would not insist on how sacred is the tree or the light,

or how sacred is what moves us-

I'd become a storyteller.

And out of our inevitable estrangement

I'd make us up again and again.

\section{Tattoo}

Bajó un espiritu

y al oído borracho nos susurró

marquen sus vientres con rosas silvestres $y$ entre cervezas nos soñé

soldados extrañando a nuestras madres eso explica aquellos diecisiete años

y el salón de tatuajes con olor a barco y motocicletas, a cuero, a océano, a mariguana y sangre de hombres tristes. 


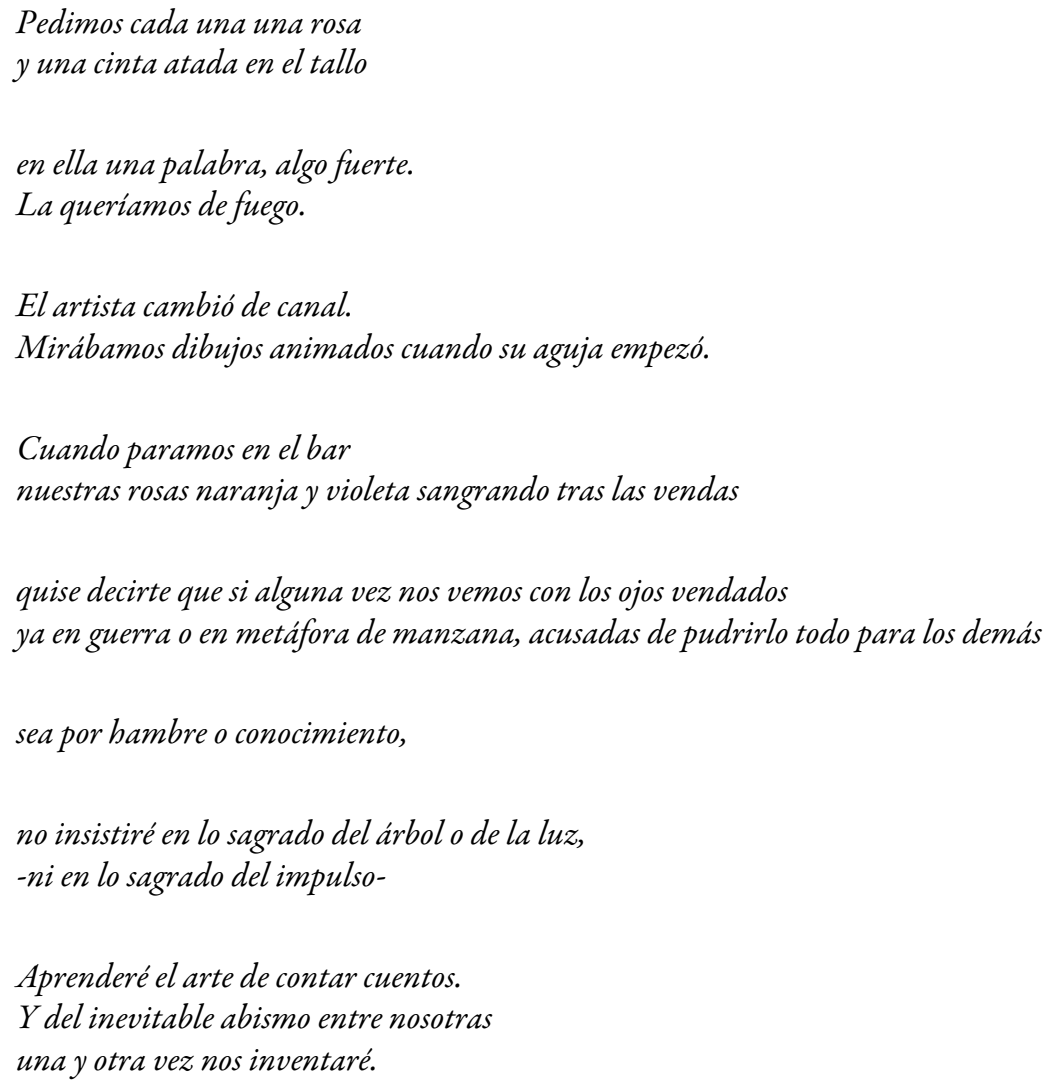

\section{The Cardinal Delivers Us}

Baptize the cardinal in our yard when I ask: where is my mother?

When I ask: where is my mother? marvel at the cardinal you've named

for she flew to us

an ember among the ovenbirds.

What truths can a cardinal sing? $A$ bird knows a bird's song attracts its own fate, not ours

We are a swirl of red feathers on a canvas. We are a scarlet flutter in a poem.

I'd climb the almond tree, climb the brick wall, and follow the cat to learn how the cat finishes the cardinal.

\section{El cardenal nos libra}

Hay bautismo de cardenal en el patio cuando pregunto: ¿dónde está mi madre? 
Cuando pregunto: ¿dónde está mi madre? maravillate del cardenal bautizado

porque viene a nosotras

brasa entre los horneros.

¿Qué verdades puede cantar un cardenal?

El ave conoce la canción del ave

atrae su sino, no el nuestro.

Somos remolino de plumas rojas en la tela. Somos temblor escarlata en el poema.

Me treparia al almendro,

a la pared de ladrillos,

en pos de ese gato

para ver cómo acaba con el cardenal.

\section{Midnight Convergence on the Ravaged Heart}

Heart, I've confused you with a tambourine again.

Shake in, shake in life, life, come, come life, come, corazón.

An exodus echoes through the rooms of this violet streaked brain.

I am a lonely daughter tonight.

There is an exodus in this house.

The water boils. The water bubbles.

Come see my angels.

Come play with the angels I've made for the blue sea.

Come have tea.

Invite me, clearly, home this year.

Oh mamá, this rose is a rock.

The rock in your hand is the rock from the ground. And headless uncles gallop through my rooms

claiming we don't love them, we don't love them anymore.

They don't stop, these potlucks for the dead.

Call and keep me, and take what you called for.

The moon is a cold rock above.

Heads find their barbed wire spines before dawn.

\section{Convergencia de medianoche sobre el corazón arrasado}

Corazón, te he vuelto a confundir con una pandereta. Agitate, agitate vida, vida, veni, veni vida, veni, heart.

Se oye el eco de un éxodo en las estancias de este cerebro jaspeado de violeta

Hija en soledad soy esta noche.

Hay un éxodo en esta casa. 
Hierve el agua. El agua burbujea. Veni a ver mis ángeles.

Veni a jugar con los ángeles que he hecho para el mar azul. Veni a tomar el té.

Invitame, claramente, a casa este año.

Oh mom, esta rosa es roca.

Esta roca en tu mano es la roca del suelo.

$Y$ hay tios decapitados galopando en mis piezas

se quejan de que no los queremos, de que no los queremos más.

No se acaban, estas cenas en honor a los muertos.

Llamame y quedate conmigo, llevate lo que pedias, eso.

La luna es una roca fría allá arriba.

Antes del alba las testas hallan sus espinazos de alambre de púa.

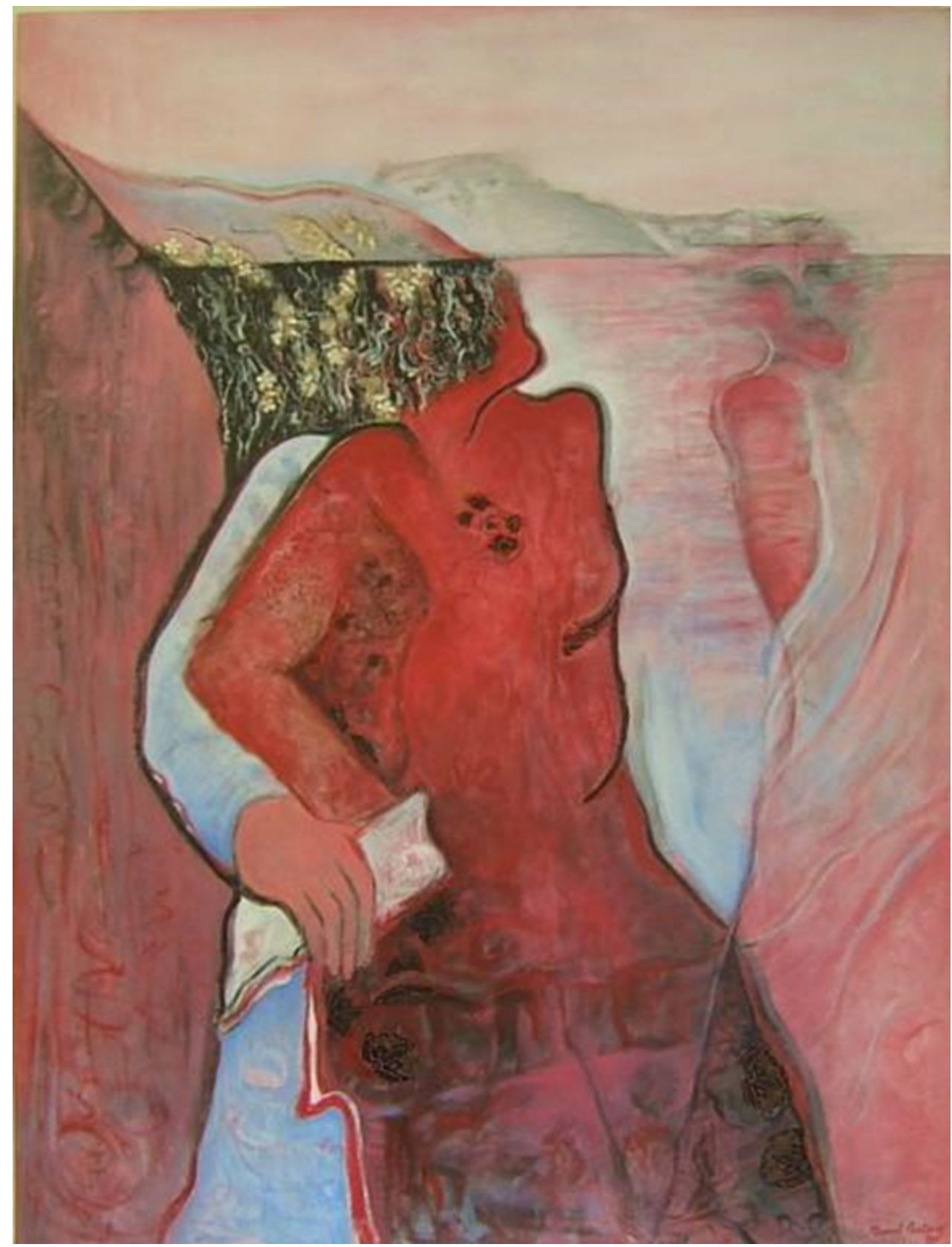

Imagen: "Rubí”, de Raquel Partnoy 


\section{Ruby}

After Rubí, painting by Raquel Partnoy

I

W're supposed to be out there on the sofa but

now she's gone through this lady's fuck-clothes,

lipstick, and whatnot. And she's in the fuck-mirror high as hell,

eyes halved, hand hipped, head titled back, and blowing

fuchsia kisses; her kisses ricocheting mirror me her mirror me her.

"Take a picture for my grandma," she smiles

wearing this lady's black negligee. Her tits want me

to suck them or rip her out of that lace.

\section{II}

The painter goes scarlet on scarlet for this one.

This girl's problem: her whole story is a problem.

Her tongue and lifeline suffer from reticence.

The wreckage alights on oxygen's vivid mouth and sucks.

\section{III}

Smack about nasty bitches she's gonna beat floats like blown out dandelion seed puffs into the coke mirror of her mangled story. The painter blurs the girl's face.

\section{IV}

"You are a very angry young woman!" hisses the Dean of Students.

"Do you even like Americans? Sounds like you hate us," alleges the man in the audience.

"No. No. No," pleads the girl, "It's that I've never been good with the needle and thread of words."

"No. No. No," pleads the girl, "It's that I've never been good at capturing the nuances of Bambi's mother getting shot."

$\mathrm{V}$

The painter knows that her subject knows love's deadlines, will mock them both. Neither are prone to light laughter. Distance, the white-suited, headless pimp holding a stack of undelivered mail in his pink hands, will smother them both. 


\section{VI}

"You just need to know how to crack a cunt in the right place," says the torturer handing the ink and stamp to the secretary in charge of censuring and withholding the letters written by the caged mothers to their children

\section{Rubi}

Por "Rubí", cuadro de Raquel Partnoy

\section{I}

Se supone que estemos allá en el sofápero ahora ella se pierde tras la figura de esa dama, su ropa de coger su rouge y no sé qué más. Y se ve en ese espejo de coger, carajo, tan alto,

ojos entornados, mano a la cintura, cabeza hacia atrás, soplando besos fucsia que rebotan reflejos en mi reflejándome en ella. "Sacá una foto para la abuela", sonrie usando el negligee negro de la dama. Sus tetas quieren que las chupe o que la arranque de su encaje.

II

La pintora ha puesto escarlata sobre escarlata aqui.

El problema de la nena: toda su bistoria es un problema. Su lengua y la cuerda de salvataje sufren de reticencia.

Los restos del naufragio se encienden en la boca vivida del oxígeno y chupan

III

Sopapos a las sucias putas a las que habrá de derrotar flotan como semillas de cardo al viento

soplan sobre la coca en el espejo de su historia mutilada. La pintora esfuma el rostro de la nena.

$I V$

“Sos una jovencita llena de rabia!" sibilante afirma la Secretaria de Asuntos Estudiantiles

“Te caemos bien los norteamericanos? Parece que nos odiaras", arguye un hombre del público

"No, no, no", se defiende la nena, "Es que nunca he sido buena para la aguja y el bilo de las palabras".

"No, no, no", se defiende la nena, "Es que nunca he sido buena para captar la sutileza del disparo a muerte sobre la madre de Bambi."

V

La pintora sabe que su modelo conoce los plazos del amor, se burlará de ambas Ninguna es dada a la risa fácil. Distancia, un cafisho trajeado de blanco, sin cabeza lleva en las manos rosadas una pila de cartas sin enviar, aplastará a las dos. 
$V I$

"Sólo necesitás saber quebrar una concha en el lugar exacto",

dice el torturador dando sello y tinta al secretario

a cargo de censurar y retener las cartas

escritas por las madres enjauladas a sus crías.

\section{RefERENCiAS}

Bloch, G. R. (2004). Unfree Associations. A Psychoanalyst Recollects the Holocaust. Los Angeles: Red Hen Press.

Partnoy, A. (2006). La Escuelita. Relatos testimoniales. Buenos Aires: Editorial La Bohemia.

Partnoy, R. (2013). Ciudad de rojos horizontes. Bahía Blanca: Hemisferio Derecho Ediciones.

Sanabria, R. I. (2009). The Strange House Testifies. Arizona: Bilingual Press.

\section{Notas}

1 Adjunto este video de la charla: https://youtu.be/2StArMFV5Og. En el minuto 37 comienza la presentación de mamá. 